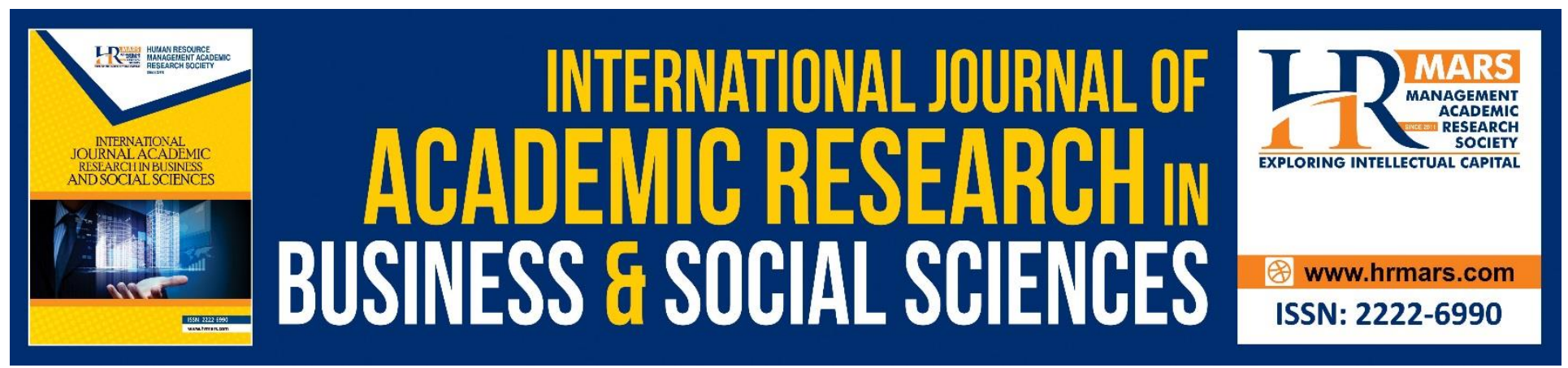

\title{
Factors Affecting Brand Relationship Quality of Halal Food and The Mediating Role of Halal Literacy
}

\section{Mussadiq Ali Khan, Sharizal Hashim, Muhammad Yaseen Bhutto}

To Link this Article: http://dx.doi.org/10.6007/IJARBSS/v11-i14/8576

DOI:10.6007/IJARBSS/v11-i14/8576

Received: 18 December 2020, Revised: 02 January 2021, Accepted: 16 January 2021

Published Online: 29 January 2021

In-Text Citation: (Khan et al., 2021)

To Cite this Article: Khan, M. A., Hashim, S., \& Bhutto, M. Y. (2021). Factors Affecting Brand Relationship Quality of Halal Food and The Mediating Role of Halal Literacy. International Journal of Academic Research in Busines and Social Sciences. 11(14), 301-316.

Copyright: (C) 2021 The Author(s)

Published by Human Resource Management Academic Research Society (www.hrmars.com)

This article is published under the Creative Commons Attribution (CC BY 4.0) license. Anyone may reproduce, distribute, translate and create derivative works of this article (for both commercial and non-commercial purposes), subject to full attribution to the original publication and authors. The full terms of this license may be seen at: http://creativecommons.org/licences/by/4.0/legalcode

Special Issue: Contemporary Business and Humanities Landscape Towards Sustainability, 2021, Pg. 301 - 316 http://hrmars.com/index.php/pages/detail/IJARBSS JOURNAL HOMEPAGE

Full Terms \& Conditions of access and use can be found at http://hrmars.com/index.php/pages/detail/publication-ethics 


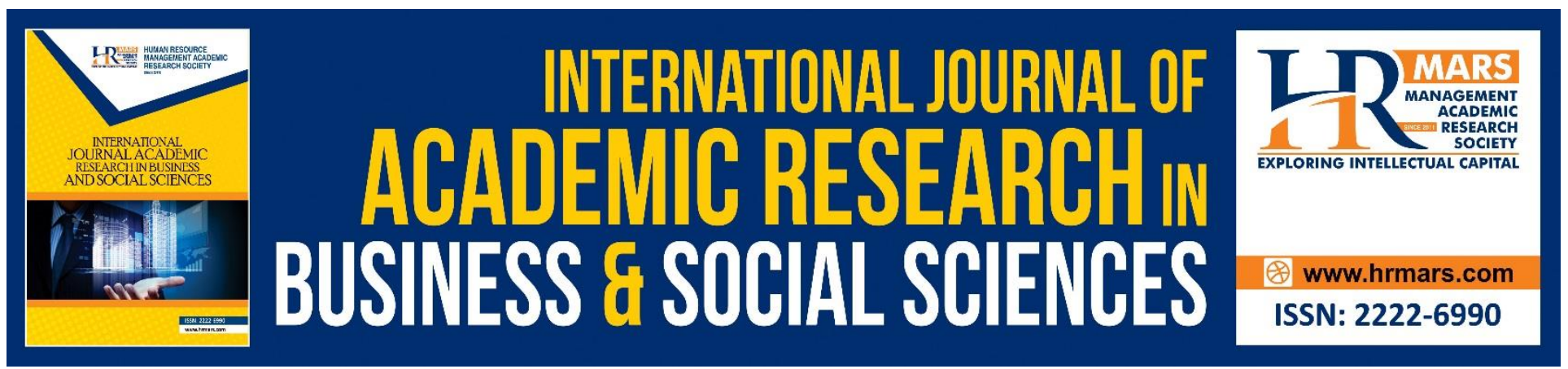

\title{
Factors Affecting Brand Relationship Quality of Halal Food and The Mediating Role of Halal Literacy
}

\author{
Mussadiq Ali Khan, Sharizal Hashim \\ Email: Khanconnexion@yahoo.com,hsharizal@unimas.my \\ Muhammad Yaseen Bhutto \\ Wuhan University, China \\ Email: yaseen_bhutto@whu.edu.cn
}

Faculty of Economics and Business, Universiti Malaysia, Sarawak, Malaysia

\begin{abstract}
Purpose: Brand relationship is anemerging phenomenon and companies are giving it a lot of importance. Islamic marketing is gaining grounds everywhere in the world and capturing a lot of attention in the countries where Muslims are in majority and even in minority. Present research aims to evaluate factors like brand experience, religiosity, price and role of halal literacy as a mediator to the brand relationship quality of halal food brands.

Methodology: Survey research method has been conducted in Kuching and Kota Samarahan cities of Sarawak State, Malaysia. 270 respondents took part in this research. The partial least square method (PLS-SEM) has been used for data analysis.

Findings: The findings of the research suggest that experiential value, price, and religiosity have effect on brand relationship quality of halal food brands. The role of halal literacy as a mediator has been found significant in respect of experiential value and religiosity, while it remained unchanged in determining the price.

Research Limitation: The research has been conducted by applying cross sectional data method. The study is limited to the state of Sarawak, Malaysia and it concerns only the food products.

Practical Implication: The findings of this research can be considered as a help by brand managers in formulating their marketing and business strategy.

Originality/Value: This research endeavoured to explore the importance of religiosity in customerbrand relationship of halal food brands. Moreover, the concept of the mediation role of price transparency has been investigated for the first time. It indicates that this area has never been explored before in research.
\end{abstract}

Keywords: Religiosity, Price, Experiential Value, Halal Brands, Brand Relationship Quality. 


\section{Introduction}

The One of the newly emerging marketing concepts is Islamic branding which is gaining attention of academicians, practitioners, businessmen and consumers due to multiple reasons. Islamic market is comprised of 1.6 billion or 23 percent of the whole world market (Yuhas, 2015). Muslim consumers are in majority in approximately 56 countries of Africa, Asia and Europe. Islam is the fast growing religion in the world which has direct impact on increasing number of Muslim consumers of halal food. Islamic market is touching colossal US \$2.7 trillion in 2007 and it is estimated that it will be US\$ 30 trillion by 2050 (JWT, 2007). Relationship with consumer is also interesting area for researchers now a days due to various reasons including role of customers in brands building has increased in this modern market. The concept that brand and consumers are related to each other is known as customer brand relationship or brand relationship (Hashim \& Yasin, 2017; Fournier, 1998; McAlexander, Schouten, \& Koenig, 2002; Sheth \& Parvatiyar, 1995). Brand relationship concept has multiple advantages like reduced marketing cost, easy to access consumers, bringing new customers, brand equity, retention of customer, and earning maximum profit (Dowling, 2002; Winer, 2001).

In the past, companies spent a lot of money on marketing activities like advertising to acquiring new customers rather than retaining loyal consumers. Present time has witnessed considerable change in the previously practiced market philosophy. Companies have changed their strategies and most of the efforts are focused on strengthening relationship with consumers that are also called as relationship marketing (Peelen, 2003). Relationship marketing has been widely researched and two new perspectives have emerged in this area. Investigation of buyers' side (Dwyer, Schurr, \& Oh, 1987; Crosby, Evans, \& Cowles, 1990; Moorman, Zaltman, \& Deshpande, 1992), and seller side which gave a broad view discussed by Morgan and Hunt (1994). After 2000, relationship marketing evolved with investigation in comprehensive relation marketing overview. Approximately, in the past thirty years, relationship marketing witnessed a big evolution and studies conducted in different sectors started from automobiles (Kumar, Scheer, \& Steenkamp, 1995; Morgan \& Hunt, 1994; Dwyer et al., 1987), financial services (Malarvizhi et al., 2018; Bejou et al., 1996; Zineldin, 1995), tourism and hotel services (Ryu \& Lee, 2017; Huang et al., 2006; Kim \& Cha, 2002) and store and retail (Ramaseshan et al., 2006; Wong \& Sohal, 2002). Some studies have been conducted like Zainol et al (2014), which focussed on brand identity and brand commitment. But in in the context of Islamic branding, brand relationship quality has rarely been investigated. Secondly, the relationship between Islamic brands' consumers and halal food brands has scarcely been studied. Thirdly, no considerable study has been conducted to examine halal food literacy in terms of attracting more Muslim consumers. So, this study aims to examine the impact of halal food literacy among halal food consumers.

Research in Islamic marketing and relationship marketing is evolving as new area but it is on early stages. Hence, it invites the need for deeper investigation on finding the important factors in establishing the relationship between consumers and the halal products and the important role of halal literacy in influencing the relationship. The findings of such investigation would, hopefully, be helpful for market managers in formulating strategies to attract more consumers and develop a relationship between them and consumers. The relationship would ultimately establish trust between the two sides that would help the managers tochalk out strategies about particularbrand/product/services. This study has been carried out with two prime objectives. First, it examines the effect of the factors behind Muslim consumers' behaviour towards brand relationship 
INTERNATIONAL JOURNAL OF ACADEMIC RESEARCH IN BUSINESS AND SOCIAL SCIENCES

Vol. 11, No. 14, Contemporary Business and Humanities Landscape Towards Sustainability. 2021, E-ISSN: 2222-6990 @ 2021 HRMARS

quality based on the theory of social exchange. Second, it helps in measuring and investigating the mediating role of halal food literacy.

\section{Literature Review}

\section{Concept of Halal and Islamic Branding}

The Holy Quran clearly defines-Halal and Haram. Quran clearly tells every Tayyab (clean, pure) is Halal and lawful while Haram means khabith (bad, impure) (Al-Quran, 7:157). Adding to this, Holy Quran clearly teaches its followers about concepts of Haram and Halal in these verses as "O Mankind! Eat of which is Halal (Lawful) and Tayyab (good) on the earth and follow not the footstep of Satan. Verily, he is to you an open enemy (Al-Quran 2:168). In addition to elaboration of perspectives of Halal and Haram, Islam suggests about spending pattern in this way "O children of Adam! Wear your beautiful apparel at every time and place of prayer, eat and drink but waste not by excess, For Allah loveth not the wasters" (Al-Quran, 7:31-32). "Not equal are things that are bad and things that are good, even though the abundance of the bad may dazzle thee; so fear Allah, o you who understand, so that you may prosper" (Al-Quran,5:103).

Islam is not limited to religious activities but it also recommends some ways about practical life to its followers like counselling about business and marketing activities. Prophet Muhammad (P.B.U.H) himself showed every aspect of practical life. Furthermore, prophet (P.B.U.H) explains teaching of Islam in this way "One who cheats (Ghassh) is not one of us (AN-NAWAWI, 1989). It clearly reflects seller should explain and clarify all of features of products to consumers so that consumers should not feel any kind of deception from seller (Niazi, 1991). From Islamic point of view, it is suggested that all the connection and communication regarding products must be disclosed and any sort of promotional behaviour or manipulative advertisement should not be used in which consumers basic instincts are manipulated in any way (Shaw \& Barry, 2015). Teaching of the Holy Prophet (P.B.U.H) between customer and company relationship are clear and guides in this way "the seller and the buyer have the right to keep or return the good as long as they have not parted; and if both the parties spoke the truth and described the defects and qualities [of the goods]; then they would be blessed in their transaction, if they told lies or hid something, then blessing of transaction would be lost".

Islamic brands have gained much attention in recent times. Islamic branding comprises few types. First, is to consider the compliance perspective in which brands follow Shariah, e.g. Dubai Hotel. Second, brands are considered Islamic by originally being from Islamic countries. The Islamic originality is helpful in the promotion of a brand. e.g. Emirates and Egyptian Orascom. Third, brands are categorized as Islamic on the basis of its consumers. This means that the brand's origin is not a Muslim country but it targets to attract the consumers in Muslim countries, e.g. KFC, Nestle, and Unilever (Jumani \& Siddiqui, 2012).

The above mentioned discussion shows that Islamic branding has healthy and considerable presence in 1.3 billion consumers in the world. However, this is important to define what factors should be considered important in determining the features and characteristics of a brand as Islamic which should be maintained according to the principles of Shariah.

Brand experiences are pivotal factor for customer to establish good relationship with the brand including halal brand. Researchers are focused on experience because it is first ladder of developing relationship with consumers and it may prove decisive for both consumers and brands (Jung \& Soo, 
2012). Creation of experiential valuegenerates optimum level of benefits and profit among companies and customers interchangeably (Wong \& Tsai, 2010). Brand experience happens when consumers encounter products during search process and consume services or products (Brakus, Schmitt, \& Zhang, 2008; Holbrook, 2000). Halal brand is rising phenomenon due to its large consumer market. Therefore, it is vital to investigate brand experience and its importance for Halal brands and market potential.

Besides that, customers of Islamic branding have been investigated through various dimensions to know their intention and behaviour about products. One of the significant factors which determine choice or intention of consumer is price (Natarajan, Balasubramanian \& Kasilingam, 2017; Grewal, Krishnan, Baker \& Borin, 1998; Chang \& Wildt, 1994). Pricing is crucial for making choices and it is more important in current worst economic situations. Specifically in developing countries, price is ultimate factor for product buying intention (Natarajan et al., 2017; Roy et al., 2016). So, pricing has gained central role today. However, in Islamic branding context, factor of price is under researched so, it is significant to understand about role of price in brand relationship quality of Islamic brand.

Another important factor involved in Halal brand is religiosity. Religiosity impacts on consumer through four ways (belief, rituals, values and community) and it is connected with many kinds of conditions and consumer states that will lead to effect in consumption (Mathras et al., 2016). Religiosity assists consumers in adopting certain attitude and behaviour, moreover, it is foundation through which consumers opt certain behaviour for their choices (Essoo \& Dibb, 2004; Mukhtar \& Butt, 2012). Consequently, having such vast potential and large market, there must be debate about Islamic branding, religiosity and their way of establishing relationship with its customers. Due to various factors like large population or customer base, Islamic consumers market and Islamic branding is under focused among researchers at large (Zainol et al., 2014; Al-Harran \& Low, 2008; Frost, 2007).

In addition, awareness about products is important but in some purchases consumers must be able to differentiate some products from others like in Islamic brands. Moreover, consumers must know what products are permissible or prohibited. Without giving awareness to consumers, it may notbe possible that customers of Islamic brands could build maximum relationship with Islamic brands. So importance of halal literacy cannot be denied (Salehudin, 2010). Without Halal literacy, judgment of Islamic consumers will be full of doubts because Halal literacy creates differentiation for products among Halal consumers (Salehudin, 2010). Concept of Halal literacy is important to examine because like traditional marketing, and in Islamic branding too, consumers have to go through a rigorous process from searching of products to consumption (Antara, Musa, \& Hassan, 2016). Study conducted by Ismail and Ibrahim (2011), revealed that Malaysian consumers have varying level of literacy and it hints at halal literacy gap which can put Muslims at risk for their consumption of food.

As illustrated in Figure 1, the conceptual framework is based upon 'Social Exchange Theory or SET,' because this theory has addressed the factors important formutual benefits which provide real ground for customer brand relationship. In this way, both sides have to get benefit after paying its particular cost. SET clearly describes about benefit exchange especially about reward and cost that are foundations of theory (Homans, 1961). 'Theory of Social Exchange' assumes that people tend to maximize the profit, they are rational and they try to maximise the reward by analysing the situation and adopt the one that suits them. So, the study infers that Halal brand relationship will be strengthened and flourished when favourable behaviour will be established with consumer. By 
creating better experiential value, price positioning, and religiosity of customer will create more favourable customer-brand relationship. If brand provides more justification for experiential value, pricing, and religiosity, then ultimately, brand would be able to attract relationship between customer and brand. In addition to it, the more the customers will be aware about halal food, the more it would be easy for them to create likeness for brand. Theory of Social Exchange explains it all and also it narrates how this phenomenon works.

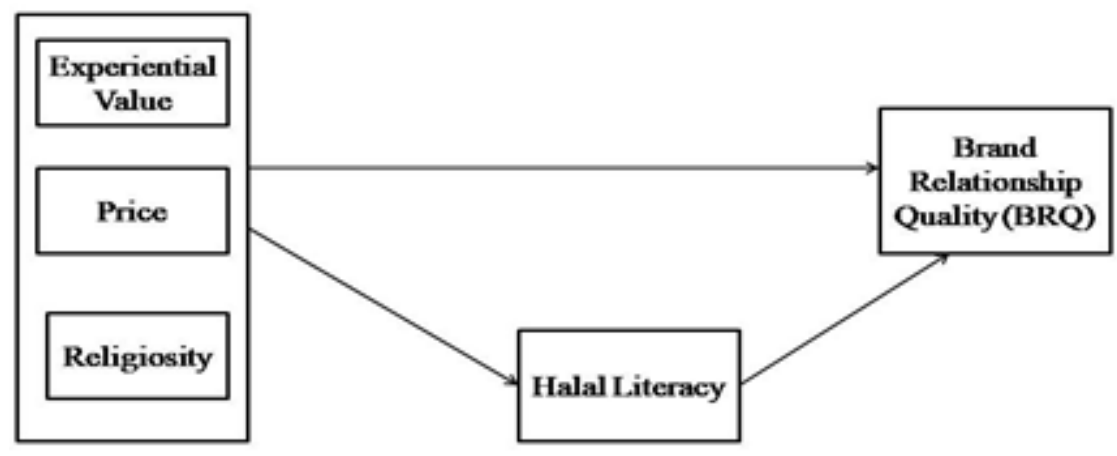

Figure 1: Conceptual Framework

Experiential value and brand relationship quality

Marketing has moved from traditional marketing to relational marketing. So customer brand relationship has become pivotal concept to explore. Holbrook (1994) defined experiential value as outcome of inner pleasure that is achieved after consumption of product. Generally, experiential value is important for consumer's purchase intention and it helps consumers to decide about relationship with some specific brands. Experiential value comprises of interaction between brand and buyers. Moreover, to establish relationship with brandsas a first ladder, consumers have to interact with brand. Through literature review, it is concluded that impact of brand experience is positive on customer brand relationship (Del Rio et al., 2001; JoskoBrakus et al., 2009; Iglesias et al., 2011; Park et al., 2013; Nysveen et al., 2013; Tuskej et al., 2013; Kumar \& Kaushik, 2018; Yusoof et al., 2016). This concept has been under study for years in traditional marketing, but in area of Islamic branding, this phenomenon has not been sufficiently investigated. The situation invites the interest of researchers to study and explore the huge Muslim consumer market and investigate its customer brand relationship.

Keeping in view the above-mentioned situation, this study hypothesizes the following:

$\mathrm{H} 1$. Experiential value has positive effect on brand relationship quality of Islamic brands.

\section{Price and Customer Brand Relationship Quality}

Current developments of modern world like information technology and communication made it easier to consumers to realize importance of brand price. Similarly, the awareness made the consumers more sensitive about brand price (Grewal et al., 1998). In addition to it, one of the important quality decision determinants of brand is price (Park et al., 2019). However, making decision about product is first step towards building relationship with brands and it is the price which is prime element that helps in taking decision about particular brand (Lalwani \& Monroe, 2005; Park et al., 2019). If there is choice available before Muslim consumers then preference will be given to a 
brand that offers competitive price and better products. In this way, it would be easier for consumers to establish relationship with particular brand. Like traditional branding concepts, price is important element for purchase decision in Islamic marketing as well. Price is also significant for building relationship with brands. However, price has been rarely investigated in context of Islamic brands. So, the study proposes the second hypothesis as follows:

H2. Price positively affects customer brand relationship of Islamic brands.

\section{Religiosity and Brand Relationship Quality}

Religion assists consumers in adopting certain attitude and behaviour and it is the foundation through which consumers opt certain behaviour for their particular choices (Essoo \& Dibb, 2004; Mukhtar \& Butt, 2012). Impact of religion on consumer can be described through four ways (belief, rituals, values and community). Moreover, it is connected with various conditions and many consumers' circumstances that lead to the effect in final consumption of consumers (Mathras et al., 2016). Religiosity is acomplex construct and its assessment is based upon judgment of religion (Al Abdulrazak \& Gbadamosi, 2017). According to McDaniel and Burnett (1990), religiosity is defined as "belief in God accompanied by a commitment to follow principles believed to be set by God". Through the angle of culture, consumer interprets the message that is needed for adopting such response after translating certain marketing communication (De Run, Butt, Fam, \& Jong, 2010). It is noted that researcher expressed lesser interest (not at required level) despite the fact that this concept has potential to explore (Salam, Muhamad, \& Leong, 2019). In choosing Islamic brands, religiosity plays central role and religion is main motivation behind establishing relationship with Halalproducts. However, particular role of religiosity in establishing relationship with Islamic brand is an area which is under researched. So, the study presents the third hypothesis as follows:

H3. Religiosity is positively related to customer brand relationship of Islamic brands.

\section{Halal Literacy as a Mediator}

Halal literacy is defined as "an ability of a person's combining set of knowledge, awareness, and skills to differentiate between halal and haram goods and services based on Shariah Law" (Antara et al., 2016). Halal literacy can also be defined as "ability to differentiate between permissible (Halal) and non-permissible (Haram) goods and services which came from better understanding of Islamic law" (Salehudin, 2010). In traditional marketing, there is little literature about literacy of consumers. However, financial literacy is discussed by few researchers (Lewis, Mimura, Mauldin, Rupured, \& Jordan, 2008; Hu et al., 2009).

Factors like experiential value, price and religiosity not only impact on brand relationship quality of Halal but also help in developing better consumer's literacy about halal products to play its due role in strengthening relationship of brand with its respective customers. In current study, it is proposed that experiential values, price, and religiosity have positive relationship with brand relationship quality of Halal. And Halal literacy significantly and positively mediates between these factors. For instance, experience of consumption of the products like aesthetics, playfulness, and service excellence clearly determines customer's relationship with specific brand. Additionally, consumer's halal literacy is significant for Halal consumers, for example knowing better Shariah, its code of conduct, concept of Halal and Tayyab improves with every experience of brand that leads to help the consumer to play its role indetermining consumer-brand relationship. 
Similarly, effect of religiosity is evident on customer's relationship with Halal brands. In the same fashion, religious belief like better understanding about Islam is a pivotal factor for nurturing better relationship with Halal brands. Moreover, religiosity is quite linked with Halal literacy. High religiosity is positively related with Halal literacy means highly literate about Halal, its code of conduct, Halal and Haram concept and vice versa. Likewise, price has also impact on building relationship with Halal brands. It is quite obvious that aperson who is willing to pay high price is highly likely to be more aware about Halal and will be better able to analyse its relationship with Halal brands. This Halal literacy concept is also little researched (Salehudin, 2011; Ismail \& Ibrahim, 2011), and it is our study which is taking Halal literacy as mediator. In traditional marketing, Halal literacy is rarely discussed.So, it is better to know about Halal literacy. Thus, Muslim consumers who have better understanding about concept of Halalmust be more careful and more involved in their respective brands. Without Halal literacy, it would not be possible to know the effect of experiential value, price and religion on brand relationship quality. So, the study presents the fourth, the fifth and the sixth hypothesis as follows:

H4: Halal literacy positively mediates between price and Halal brand relationship quality.

H5: Halal literacy positively mediates between experiential value and halal brand relationship quality H6: Halal Literacy positively mediates between religiosity and Halal brand relationship quality

\section{Research Method}

\section{Data Collection, Measurement and Sample}

Self-administered questionnaire was developed and comprised of two sections. First section consisted of demographic details and second section questions about price, religiosity, halal literacy, brand experience and brand relationship quality. Measurement of religiosity is adapted from Welch, Tittle, and Grasmick (2006), brand experience (Holbrook, 1994), price (Ofir, 2004), Halal literacy (Salehudin, 2010), and brand relationship quality (Chang \& Chieng, 2006). Survey was distributed via online Google form among Muslim consumers of Kuching and Kota Samarahan and assurance was given to theconsumers that sole purpose of this survey is academic and confidentiality of information will be promised. Using convenience sampling technique, 300 questionnaires were distributed, and 270 consumers response was received. Hence, response rate was (90\%). The details of demographics are as follows:

Table 1: Respondents Demographic

\begin{tabular}{|c|c|c|c|}
\hline Variable & Category & Frequency & Percentage(\%) \\
\hline \multirow[t]{2}{*}{ Gender } & Male & 132 & 49 \\
\hline & Female & 138 & 51 \\
\hline \multirow[t]{3}{*}{ Age of respondent } & $18-23$ & 55 & 20.37 \\
\hline & $24-35$ & 175 & 64.8 \\
\hline & 35-above & 40 & 14.81 \\
\hline \multirow{4}{*}{$\begin{array}{l}\text { Frequency and } \\
\text { purchase value of } \\
\text { Halal product in } \\
\text { one year }\end{array}$} & RM 1600 and above & 126 & 46.7 \\
\hline & Less than equal to RM 1100-1500 & 32 & 11.7 \\
\hline & Less than equal to RM 600-1000 & 63 & 23.3 \\
\hline & Less than equal to RM 500 & 49 & 18.3 \\
\hline
\end{tabular}

Source: developed by author 
INTERNATIONAL JOURNAL OF ACADEMIC RESEARCH IN BUSINESS AND SOCIAL SCIENCES

Vol. 11 , No. 14, Contemporary Business and Humanities Landscape Towards Sustainability. 2021, E-ISSN: 2222-6990 ㄷ 2021 HRMARS

Majority of the respondents who took part in this research, were in age group 24-35 (64.8\%), 138 (51\%) females and 132 (49\%) were male respondent and spend approximately RM 1600 and above (46.7\%) for Halal product in one year.

\section{Findings and Discussion}

This study used smart PLS to test validation and the measurement of structural model. For internal reliability, factor loading of each item was calculated and item loading lower than 0.50 was removed from proposed model due to reason that it could not explain variance in the model. Keeping in view the common bias method, Harman One Factor testing through SPSS 16.0 was performed to measure about common method bias. Harman One Factor test is a non-rotating exploratory factor analysis of an instrument or questionnaire. If a single factor is unable to explain most of the variance (0.50) in this test, it tells that no common method bias is found. For this study, the single factor accounted for barely $40 \%$ of the variance of whole instrument. Consequently, there is no common method bias as depicted in Table 2.

Table 2: Factor Loading Summary

\begin{tabular}{|c|c|c|c|c|c|}
\hline Dimensions & \multicolumn{2}{|c|}{ Factor Loading } & $\begin{array}{l}\text { Cronbach's } \\
\text { Alpha }\end{array}$ & $\begin{array}{l}\text { Composite } \\
\text { Reliability }\end{array}$ & $\begin{array}{c}\text { Average Variance } \\
\text { Extracted (AVE) }\end{array}$ \\
\hline \multirow{4}{*}{ EXPERIENTIAL VALUE } & EV1 & 0.784 & \multirow{4}{*}{0.709} & \multirow{4}{*}{0.817} & \multirow{4}{*}{0.529} \\
\hline & EV2 & 0.709 & & & \\
\hline & EV3 & 0.705 & & & \\
\hline & EV4 & 0.707 & & & \\
\hline \multirow{4}{*}{ PRICE } & P1 & 0.888 & \multirow{4}{*}{0.837} & \multirow{4}{*}{0.888} & \multirow{4}{*}{0.667} \\
\hline & P2 & 0.854 & & & \\
\hline & P3 & 0.794 & & & \\
\hline & P4 & 0.718 & & & \\
\hline \multirow{4}{*}{ RELIGIOSITY } & $\mathrm{R} 1$ & 0.888 & \multirow{4}{*}{0.812} & \multirow{4}{*}{0.878} & \multirow{4}{*}{0.644} \\
\hline & $\mathrm{R} 2$ & 0.877 & & & \\
\hline & R3 & 0.775 & & & \\
\hline & R4 & 0.684 & & & \\
\hline \multirow{8}{*}{$\begin{array}{c}\text { BRAND } \\
\text { RELATIONSHIP } \\
\text { QUALITY }\end{array}$} & BQ1 & 0.804 & \multirow{8}{*}{0.901} & \multirow{8}{*}{0.92} & \multirow{8}{*}{0.591} \\
\hline & $\mathrm{BQ2}$ & 0.795 & & & \\
\hline & $\mathrm{BQ3}$ & 0.734 & & & \\
\hline & BQ4 & 0.764 & & & \\
\hline & BQ5 & 0.736 & & & \\
\hline & BQ6 & 0.718 & & & \\
\hline & $\mathrm{BQ7}$ & 0.813 & & & \\
\hline & $\mathrm{BQ8}$ & 0.78 & & & \\
\hline \multirow{4}{*}{ HALAL LITREACY } & HL1 & 0.52 & \multirow{4}{*}{0.787} & \multirow{4}{*}{0.865} & \multirow{4}{*}{0.625} \\
\hline & $\mathrm{HL2}$ & 0.849 & & & \\
\hline & HL3 & 0.865 & & & \\
\hline & HL4 & 0.871 & & & \\
\hline
\end{tabular}

Source: developed by author 
Convergent reliability is measured through composite reliability $(C R)$ of all the constructs of the model range from 0.812 to 0.92 , while on the other hand, average variance extracted (AVE) ranges from 0.529 to 0.667 that falls under the accepted standard recommended by Hair (2015). To verify the discriminant validity of the constructs, square root of the average variance scores for whole construct was used. If the square root of the AVE is better than the shared variance between the constructs, the investigator can declare the discriminant validity between the constructs. Table 3 shows that model has discriminant validity because of the reason that square root of the AVE for every construct is better than the common variance between the constructs.

Table 3 Correlation matrix

\begin{tabular}{|c|c|c|c|c|c|}
\hline & $\begin{array}{c}\text { Brand } \\
\text { Relationship } \\
\text { Quality }\end{array}$ & $\begin{array}{c}\text { Experiential } \\
\text { Value }\end{array}$ & $\begin{array}{c}\text { Halal } \\
\text { Literacy }\end{array}$ & Price & Religiosity \\
\hline $\begin{array}{c}\text { Brand Relationship } \\
\text { Quality }\end{array}$ & 0.769 & & & & \\
\hline Experiential Value & 0.517 & 0.727 & & & \\
\hline Halal Literacy & 0.72 & 0.608 & 0.79 & & \\
\hline Price & 0.569 & 0.786 & 0.529 & 0.816 & \\
\hline Religiosity & 0.635 & 0.526 & 0.625 & 0.536 & 0.803 \\
\hline
\end{tabular}

Source: Developed by author

Hypotheses were tested through structural equation modelling. Table 4 showed the result and it is reflected through results that experience value is linked with brand relationship quality with an estimated value of (beta $=0.386$, $t$ value $=2.263$, $p$ value $=0.024$ ), while religiosity has significant effect on brand relationship quality with an estimated value of (beta $=0.423$, $t$ value $=3.860, P$ value $=0.000$ ). Moreover, price has effect on brand relationship quality with an estimated value (beta $=0.000, t$ value $=0.002, p$ value $=0.998$ ), mediation of halal literacy with religiosity with halal brand relationship quality is significant with (beta value $=0.304$, $t$ value $=3.186$ and $p$ value $=0.001$ ) while mediation of halal literacy to price is insignificant with (beta value $=0.003, t$ value $=0.002$ and $p$ value $=0.998$ ) Lastly, mediation of halal literacy is on experiential value is also significant with (beta value $=0.278$, $\mathrm{t}$ value $=2.352$ and $\mathrm{p}$ value $=0.019$ ) 
INTERNATIONAL JOURNAL OF ACADEMIC RESEARCH IN BUSINESS AND SOCIAL SCIENCES

Vol. 11, No. 14, Contemporary Business and Humanities Landscape Towards Sustainability. 2021, E-ISSN: 2222-6990 @ 2021 HRMARS

Table 4 Structural Model Assessment Summary

\begin{tabular}{|c|l|c|c|c|c|}
\hline \multicolumn{2}{|c|}{ Hypothesis } & $\begin{array}{c}\text { Original } \\
\text { Sample (O) }\end{array}$ & $\begin{array}{c}\text { T Statistics } \\
(\mid \text { O/STDEV|) }\end{array}$ & $\begin{array}{c}\text { P } \\
\text { Values }\end{array}$ & Results \\
\hline $\mathrm{H} 1$ & $\begin{array}{l}\text { Experiential Value } \\
\text { relationship quality }\end{array}$ & 0.386 & 2.263 & 0.024 & Accepted \\
\hline $\mathrm{H} 2$ & Price -> brand relationship quality & 0.72 & 9.755 & 0.000 & Accepted \\
\hline $\mathrm{H} 3$ & $\begin{array}{l}\text { Religiosity -> Brand relationship } \\
\text { quality }\end{array}$ & 0.423 & 3.86 & 0.000 & Accepted \\
\hline $\mathrm{H} 4$ & $\begin{array}{l}\text { Experiential Value-> Halal literacy -> } \\
\text { Brand relationship quality }\end{array}$ & 0.278 & 2.352 & 0.019 & Accepted \\
\hline $\mathrm{H} 5$ & $\begin{array}{l}\text { Price-> Halal literacy-> Brand } \\
\text { relationship quality }\end{array}$ & 0.003 & 0.002 & 0.998 & Rejected \\
\hline $\mathrm{H} 6$ & $\begin{array}{l}\text { Religiosity-> Halal literacy-> Brand } \\
\text { relationship quality }\end{array}$ & 0.304 & 3.186 & 0.001 & Accepted \\
\hline
\end{tabular}

Source: developed by author

In this study, main focus was on factors that affect brand relationship quality of Halal brands. results show that hypothesis 1 of the study $(\mathrm{H} 1)$ proved that brand experience impact on brand relationship quality among Malaysian Muslim consumers because of the reason that brand experience provides internal motivation for strength of relationship. Moreover, customers consider these factors like brand experience important for selection of brands and it is aligned with past research of Jung and Soo (2012).

Hypothesis 2 proved that price too has effect on brand relationship quality of Halal and this result is aligned with the results of Suwandhini et al (2019). The reason behind this finding can be that price helps in differentiation and choosing preferred Halal brand of customer. Another reason can be that price is central force which helps to opt and build brand relationship that offers better products offering on competitive price in this age of economic pressure everywhere in the world including Malaysia.

While on the other hand, it is clear that religiosity has effect on brand relationship quality of halal brands among Malaysian Muslim consumers and it proved true of hypothesis 3. It shows that effect of religion is on building relationship with Halal brands and it can be binding force between Halal brands and religiosity. These results confirm past study of Suhartanto et al (2019) which anticipated that religiosity has positive relationship with loyalty of Islamic banking services.

Mediation role of Halal literacy was also effective in terms of experiential value and religiosity ( $\mathrm{H} 4$ and H6) due to fact that it has significant relationship with brand relationship quality of Halal products. Moreover, every religious individual has the basic knowledge of Shariah teaching that is why halal literacy has impact on relationship between religiosity and brand relationship quality of halal brands. Another reason can be, halal literacy is founded in Islamic teaching and many centres of Islam from family to Imam of Mosque narrates it repeatedly in their own particular way. May be due to that reasons halal literacy plays its effective role in strengthening the relationship of religion with brand relationship quality of halal brands. The price factor is not mediated by halal literacy (H5) is probably because Malaysian Muslim consumers do not consider it for building relationship with 
halal brands. Consumers consider other factors like experiential value, cultural norms and religiosity more important than price when dealing with Halal and Haram products of various brands.

\section{Conclusions}

This study was focused on investigation of brand relationship quality and factors that may have impact on it. Generally, it is considered that Halal factor is less important in Muslim majority countries, but results suggest that during purchase process, large majority of Muslim population considers experiential valueand religiosity as important elements. In addition, this study extends theoretical understanding of theory of social exchange. Furthermore, marketing and advertising campaign will have more religious factors/elements then it will have far more deeper impacts on consumers. Similarly, if religiosity is considered during manufacturing process then it may produce positive outcome. However, it is noted that some factors are considered less important like Halal literacy and price in the study context. It may happen that for Muslims, religiosity is highly important than other factors in faith based products/services, and Muslims are more concerned about Halal factor in their food products in particular. It may also be possible that for religious based product, Muslim consumers give more importance to Halal productsand other factors are secondary for them.

\section{Theoretical Contribution and Limitation}

Firstly, this study contributed in terms of explaining brand relationship quality of Malaysian Muslim consumers and tried to find about important factors of brand relationship quality like religiosity in the study while building relationship with Halal brands. Secondly, theory of social exchange was extended in this aspect of Halal products. Thirdly, it has been observed religiosity factor (Shariah compliancy) is important and if more attention is paid on taking care of the products from the religious perspective, more Muslim consumers would be attracted to purchase halal products of various brands. Fourthly, it is significant for marketers and managers to know that Malaysian Muslim customers are imparting huge importance to religion for building loyalty with brands. So, they should give due importance to and consider this factor while launching advertisement campaign for Halal products. Malaysia is a Muslim majority country. So, brand manager must take due care while formulating their manufacturing/marketing plan in accordance with religious factor. However, this study was conducted in Kuching and Kota Samarahan cities of Sarawak State of Malaysia. So, this study barely reflects whole Malaysian Muslim population. This model can also be tested in other Muslim countries to check how Muslim consumers vary across different cultures. Secondly, this study was limited to general Halal food products, so it can be studied on other products like cosmetics. Thirdly, this research was conducted upon cross sectional study procedure. Future research can be based upon longitudinal studies.

\section{Acknowledgment}

This work was supported by UNIMAS's Postgraduate Student Research Grant Scheme F01/PGRG/1891/2019 


\section{References}

Al-Harran, S., \& Low, K. (2008). Marketing of halal products: the way forward. The Halal Journal, 4446.

Al Abdulrazak, R. M., \& Gbadamosi, A. (2017). Trust, religiosity, and relationship marketing: a conceptual overview of consumer brand loyalty. Society and Business Review.

AN-NAWAWI, A. (1989). Riyadh-us-Saleheen, Vol.I, Translated by SM MadniAbbasi.New Delhi: Idaralsha'at-e-Diniyat Private Limited.

Antara, P. M., Musa, R., \& Hassan, F. (2016). Bridging Islamic financial literacy and halal literacy: the way forward in halal ecosystem.Procedia Economics and Finance, 37, 196-202.

Bejou, D., Wray, B., \& Ingram, T. N. (1996). Determinants of relationship quality: an artificial neural network analysis. Journal of Business Research, 36(2), 137-143.

Brakus, J. J., Schmitt, B. H., \& Zarantonello, L. (2009). Brand experience: what is it? How is it measured? Does it affect loyalty? Journal of marketing, 73(3), 52-68.

Brakus, J. J., Schmitt, B. H., \& Zhang, S. (2008). Experiential attributes and consumer judgments, in handbook on brand and experience management, Bernd H. Schmitt and David Rogers, eds. Northampton, MA: EdwardElgar.

Chang, P. L., \& Chieng, M. H. (2006).Building consumer-brand relationship: A cross-cultural experiential view.Psychology \& Marketing, 23(11), 927-959.

Chang, T.-Z., \& Wildt, A. R. (1994). Price, product information, and purchase intention: An empirical study. Journal of the Academy of Marketing science, 22(1), 16-27.

CIA. (2009). The World Fact Book.

Crosby, L. A., Evans, K. R., \& Cowles, D. (1990). Relationship quality in services selling: an interpersonal influence perspective. Journal of marketing, 54(3), 68-81.

De Run, E. C., Butt, M. M., Fam, K. S., \& Jong, H. Y. (2010). Attitudes towards offensive advertising: Malaysian Muslims' views. Journal of Islamic Marketing.

Del Rio, A. B., Vazquez, R., \& Iglesias, V. (2001). The effects of brand associations on consumer response.Journal of consumer marketing.

Dowling, G. (2002). Customer relationship management: in B2C markets, often less is more. California Management Review, 44(3), 87-104.

Dwyer, F. R., Schurr, P. H., \& Oh, S. (1987). Developing buyer-seller relationships.Journal of marketing, 51(2), 11-27.

Essoo, N., \& Dibb, S. (2004). Religious influences on shopping behaviour: An exploratory study. Journal of marketing management, 20(7-8), 683-712.

Fournier, S. (1998). Consumers and their brands: Developing relationship theory in consumer research. Journal of consumer research, 24(4), 343-373.

Frost, R. (2007). Where are the Muslim brands.Brand Channel.

Grewal, D., Krishnan, R., Baker, J., \& Borin, N. A. (1998). The effect of store name, brand name and price discounts on consumers' evaluations and purchase intentions. Journal of Retailing, 74(3), 331.

Hair, J. F. (2015). Essentials of business research methods: ME Sharpe.

Hashim, S., \&Yasin, N. M. (2017). The impact of relational value towards customer brand relationship stickiness in the context of Malaysian public higher education service. International Journal of Business and Society, 18(2). 
Holbrook, M. B. (1994). The nature of customer value: an axiology of services in the consumption experience. Service quality: New directions in theory and practice, 21(1), 21-71.

Holbrook, M. B. (2000). The millennial consumer in the texts of our times: Experience and entertainment. Journal of Macromarketing, 20(2), 178-192.

Homans, G. (1961). Social Behavior: Its Elementary Forms, Brace \& World: New York, Harcourt.

Hu, S., Malevergne, Y., \&Sornette, D. (2009). Investors' Misperception: A Hidden Source of High Markups in the Mutual Fund Industry. Swiss Finance Institute Research Paper(09-04).

Huang, H.-H., Chiu, C. K., \& Kuo, C. (2006). Exploring customer satisfaction, trust and destination loyalty in tourism.Journal of American Academy of Business, 10(1), 156-159.

Iglesias, O., Singh, J. J., \& Batista-Foguet, J. M. (2011). The role of brand experience and affective commitment in determining brand loyalty.Journal of Brand Management, 18(8), 570-582.

Ismail, H., \& Ibrahim, H. R. (2011). Halal Literacy among Malaysian Gen-Y Consumers.JurnalPenyelidikan Islam, 24, 205-218.

Jumani, Z., \& Siddiqui, K. (2012). Bases of Islamic branding in Pakistan: Perceptions or believes. Interdisciplinary journal of contemporary research in business, 3(9).

Jung, L. H., \& Soo, K. M. (2012). The effect of brand experience on brand relationship quality.Academy of Marketing Studies Journal, 16(1), 87.

JWT. (2007), "Study reveals one of America's biggest hidden niche markets", available at: www. jwt.com/pdf/news/muslimsfocused300407.pdf

Kim, W. G., \& Cha, Y. (2002). Antecedents and consequences of relationship quality in hotel industry.International Journal of Hospitality Management, 21(4), 321-338.

Kumar, N., Scheer, L. K., \& Steenkamp, J.-B.E. (1995). The effects of supplier fairness on vulnerable resellers.Journal of marketing research, 32(1), 54-65.

Kumar, V., \& Kaushik, A. K. (2018). Destination brand experience and visitor behavior: The mediating role of destination brand identification. Journal of Travel \& Tourism Marketing, 35(5), 649663.

Lalwani, A. K., \& Monroe, K. B. (2005). A reexamination of frequency-depth effects in consumer price judgments. Journal of consumer research, 32(3), 480-485.

Lewis, J. K., Mimura, Y., Mauldin, T., Rupured, M., \& Jordan, J. (2008). Financial information: is it related to savings and investing knowledge and financial behavior of teenagers? Journal of Financial Counseling and Planning, 19(2).

Malarvizhi, C. A., Jayashree, S., Nahar, R., \& Manzoor, S. R. (2018). Identifying Post-Implementation Success Factors of Relationship Marketing: A Study on Private Banking Industry in Bangladesh.Advanced Science Letters, 24(1), 220-222.

Mathras, D., Cohen, A. B., Mandel, N., \& Mick, D. G. (2016). The effects of religion on consumer behavior: A conceptual framework and research agenda. Journal of Consumer Psychology, 26(2), 298-311.

McAlexander, J. H., Schouten, J. W., \& Koenig, H. F. (2002). Building brand community.Journal of marketing, 66(1), 38-54.

McDaniel, S. W., \& Burnett, J. J. (1990). Consumer religiosity and retail store evaluative criteria. Journal of the Academy of Marketing science, 18(2), 101-112. 
Moorman, C., Zaltman, G., \& Deshpande, R. (1992). Relationships between providers and users of market research: The dynamics of trust within and between organizations. Journal of marketing research, 29(3), 314-328.

Morgan, R. M., \& Hunt, S. D. (1994). The commitment-trust theory of relationship marketing.Journal of marketing, 58(3), 20-38.

Mukhtar, A., \& Butt, M. M. (2012). Intention to choose Halal products: the role of religiosity. Journal of Islamic Marketing.

Natarajan, T., Balasubramanian, S. A., \& Kasilingam, D. L. (2017). Understanding the intention to use mobile shopping applications and its influence on price sensitivity.Journal of Retailing and Consumer Services, 37, 8-22.

Niazi, L. A. K. (1991). Islamic law of contract: Research Cell, Dayal Singh Trust Library.

Nysveen, H., Pedersen, P. E., \& Skard, S. (2013). Brand experiences in service organizations: Exploring the individual effects of brand experience dimensions. Journal of Brand Management, 20(5), 404-423.

Ofir, C. (2004). Reexamining latitude of price acceptability and price thresholds: predicting basic consumer reaction to price. Journal of consumer research, 30(4), 612-621.

Park, H., Lalwani, A. K., \& Silvera, D. H. (2019). The Impact of Resource Scarcity on Price-Quality Judgments.Journal of consumer research.

Park, J., Han, S. H., Kim, H. K., Cho, Y., \& Park, W. (2013). Developing elements of user experience for mobile phones and services: survey, interview, and observation approaches. Human Factors and Ergonomics in Manufacturing \& Service Industries, 23(4), 279-293.

Peelen, E. (2003). Customer Relationship Management: Prentice Hall/Pearson Education, Amsterdam.

Ramaseshan, B., Yip, L. S., \& Pae, J. H. (2006). Power, satisfaction, and relationship commitment in Chinese store-tenant relationship and their impact on performance.Journal of Retailing, 82(1), 63-70.

Roy, A., Sana, S. S., \& Chaudhuri, K. (2016). Joint decision on EOQ and pricing strategy of a dual channel of mixed retail and e-tail comprising of single manufacturer and retailer under stochastic demand.Computers \& Industrial Engineering, 102, 423-434.

Ryu, K., \& Lee, J.-S. (2017). Examination of restaurant quality, relationship benefits, and customer reciprocity from the perspective of relationship marketing investments.Journal of Hospitality \& Tourism Research, 41(1), 66-92.

Saeed, M., Ahmed, Z. U., \& Mukhtar, S.-M. (2001). International marketing ethics from an Islamic perspective: a value-maximization approach. Journal of Business Ethics, 32(2), 127-142.

Salam, M. T., Muhamad, N., \& Leong, V. S. (2019). Measuring religiosity among Muslim consumers: observations and recommendations.Journal of Islamic Marketing.

Salehudin, Imam, Halal Literacy: A Concept Exploration and Measurement Validation (June 13, 2010). ASEAN Marketing Journal, 2(1), 1-12. ISSN 2085-5044, Available at SSRN: https://ssrn.com/abstract=2004762 or http://dx.doi.org/10.2139/ssrn.2004762

Shaw, W. H., \& Barry, V. (2015). Moral issues in business: Cengage Learning.

Sheth, J. N., \& Parvatiyar, A. (1995). The evolution of relationship marketing.International business review, 4(4), 397-418. 
Suhartanto, D., Ali, H. M., Tan, K. H., Sjahroeddin, F., \& Kusdibyo, L. (2019). Loyalty toward online food delivery service: the role of e-service quality and food quality. Journal of foodservice business research, 22(1), 81-97.

Suwandhini, T. A., Suwarni, E., \& Usman, O. (2019). Influence of Brand Image, Quality, and Price to Purchasing Decision Xiaomi Smartphone.Quality, and Price to Purchasing Decision Xiaomi Smartphone (January 14, 2019).

Tuškej, U., Golob, U., \& Podnar, K. (2013). The role of consumer-brand identification in building brand relationships.Journal of Business Research, 66(1), 53-59.

Welch, M. R., Tittle, C. R., \& Grasmick, H. G. (2006). Christian religiosity, self-control and social conformity.Social forces, 84(3), 1605-1623.

Winer, R. S. (2001). A framework for customer relationship management.California Management Review, 43(4), 89-105.

Wong, A., \& Sohal, A. (2002). An examination of the relationship between trust, commitment and relationship quality.International Journal of Retail \& Distribution Management.

Wong, H.-L., \& Tsai, M.-C. (2010). The effects of service encounter and experiential value on consumer purchasing behavior. Wseas Transactions on Business and Economic, 2(7), 59-68.

Yusoof, S., Faizal Iylia, F. Z., MNSR, H., Zamziba, N., \& Toriry, S. (2016). Relationship Between Economic, Political and Technology Factors: Case Study on Toyota Company. International Journal of Academic Research in Public Policy and Governace, 3(1), 53-58.

Yuhas, A. (2015), "Muslim population in Europe to reach $10 \%$ by 2050, new forecast shows", The Guardian, 2 April, available at: www.theguardian.com/world/2015/apr/02/muslimpopulation-growth-christians-religionpew (accessed 10 November 2015).

Zainol, R., Ahmad, F., Nordin, N. A., \& Aripin, A. W. M. (2014). Evaluation of users' satisfaction on pedestrian facilities using pair-wise comparison approach. Paper presented at the IOP Conference Series: Earth and Environmental Science.

Zineldin, M. (1995). Bank-company interactions and relationships.International Journal of Bank Marketing. 